\title{
SUSTAINABILITY AND THE UNIVERSITY LAW CLINIC
}

\section{Richard Owen*}

\section{Abstract}

Following increased activism, the climate crisis has moved up the political agenda, and with it an increased interest in sustainability issues. This article will look at how rebellious lawyering theory can provide a template for university law clinics when seeking to further sustainability objectives. It argues that as rebellious lawyering methods require a collective dimension to lawyering, egalitarian collaboration, deep knowledge of the communities that lawyers serve, simulations of a better future, self-examination and the building of broad coalitions it can in certain circumstances be a more effective way of furthering sustainability objectives than traditional legal process. Furthermore, building broad coalitions is vital to maintain the impetus behind sustainability initiatives.

It will reflect on the cultural change that is needed to respond to the sustainability agenda, what lessons can be learnt from the different approaches which have been taken internationally to the issue, as well as the pedagogical issues that need to be addressed to ensure that students have the appropriate sustainability literacy. It will also reflect on the extent to which sustainability is already embedded in the work of university law clinics. 
It will examine how university law clinics can respond to sustainable development legislation by using Swansea Law Clinic's experiences of working with sustainability goals and approaches, in the form of the Well-being of Future Generations (Wales) Act 2015, as a case study.

Keywords: Clinical legal education, future generations, rebellious lawyering, sustainable development, sustainability, Wales, wellbeing.

\section{Introduction $^{1}$}

"The ultimate test of a moral society is the kind of world that it leaves to its children."- Dietrich Bonhoeffer

The Well-being of Future Generations (Wales) Act 2015 (the Act), most of whose provisions came into force on $1^{\text {st }}$ April 2016, makes "sustainable development" the central organising principle of government in Wales. This article will look at how rebellious lawyering theory can be applied in order to inform a law clinic's activities when furthering a sustainability agenda. It will consider the operation of the Act to date and will argue that in certain circumstances rebellious lawyering methods are a more effective and accessible way of furthering sustainability objectives than traditional legal proceedings. 
Using Swansea Law Clinic as a case study, it will look at the extent to which sustainability is already inherent within the Clinic's activities and what still needs to be done in order to further sustainability objectives. It will also look at the pedagogical issues that need to be addressed to ensure that students have the appropriate sustainability literacy.

There has been interest in the Welsh sustainability model in other parts of the United Kingdom and internationally. There have also been important sustainability initiatives in other parts of the world. The article will evaluate the complex architecture of the Act and assess the extent to which Wales's sustainable development law is determined by its local context and the extent to which its principles transcend national boundaries.

\section{Rebellious lawyering}

Rebellious lawyering is a theory which has been developing since 1992 and is based on a rejection of "regnant lawyering" where there is a hierarchical relationship between lawyer and client with the lawyer seen as the pre-eminent problem solver. ${ }^{2}$ Regnant lawyers are seen as having only loose connections with other community groups. Their legal practice will only have a modest grasp on how so-called large 
structure - regional, national, international, political, economic and cultural forces shape and respond to the status quo. ${ }^{3}$

In contrast to regnant lawyers, rebellious lawyers seek to effect social change by empowering clients through egalitarian collaboration, as they believe grassroots activism can be more effective in bringing about social change. They stress that they are not pre-eminent in the lawyer-client relationship. ${ }^{4}$ This equality has radical implications for lawyering. It means that lawyers will not tell the client what the legal issues are but the clients themselves will be involved in framing the issue; the client will generate interventions in the community; it is the client who will monitor the success or otherwise of these interventions; and all this will require innovative organisational design. ${ }^{5}$

Although there have been a number of definitions of rebellious lawyering, what they have in common is their belief in an approach to legal practice which is socially transformative. They have a raised awareness of the tendency of legal process to individualise problems and see a community-wide dimension to many of the problems faced by socio-economically challenged communities which calls for community and social movement building. As they are wary of the tendency of

ibid 24

'What is rebellious lawyering?' (Rebellious Lawyering Institute, undated) $<$ https://rebelliouslawyeringinstitute.org/what-is-rebellious-lawyering/> accessed 2 July 2019 Anthony Alfieri, Rebellious Pedagogy and Practice, (2016) 23 Clinical L. Rev. 5, 15 
legal process to individualise problems, they need a vision of a good life in order to bring about programmatic change. This is a technique shared with those working within the sustainability space who also emphasise the need to envision a good life in the form of what a sustainable society will look like. ${ }^{6}$ There are also those within the clinical legal education movement who stress the importance of envisioning or, in other words, for seeing clinic as "...a site for imagining justice and new modes of legal practice that promote and even prefigure justice." ${ }^{7}$

Rebellious lawyers will often see the community as their client working with lay lawyers and community groups in a similar way in which public health medics see the community as their patient. There are a number of international examples of this approach of viewing the community as a client including those reaching back in time before theories of rebellious lawyering were formulated. Fifty years ago in the United States, Wexler said: “The whole notion of adversary proceeding is unsuited to dealing with social problems." ${ }^{8}$ He advocated a form of legal practice for oppressed communities orientated towards facilitating the organisation and empowerment of people rather than solving their legal problems because many problems were shared amongst members of oppressed groups. ${ }^{9}$ Bellow also talks of legal work "being done in service to individuals and larger more collectively

Jane Davidson, \#futuregen (Chelsea Green Publishing, 2020) Kindle Edition. 440

Sarah Buhler, 'Clinical Legal Education in a Dangerous Time' (2016) 23(5) International Journal of Clinical Legal Education, 23

Stephen Wexler, 'Practicing Law for Poor People' (1970) 79(2) The Yale Law Journal, 1049, 1059 ibid 1053 
orientated goals." ${ }^{10}$ Whilst in Canada the mission of Parkdale Community Services, which was founded in 1971, includes providing services based on "community needs" ${ }^{11}$ Nicholson, who has practised in South Africa, Scotland and England, says that the most beneficial form of clinical delivery for clients is that which seeks to improve the lives of members of a community by taking a multi-disciplinary, "wraparound" approach recognising the importance of legal and non-legal remedies. $^{12}$

Rebellious lawyers are grounded in their local communities and consider how large structure such as political, economic and political forces affect the ability to bring about change in these communities. As it is a form of community-based lawyering, assets such as community activism and clients' stories are of central importance. Rebellious lawyers demystify the law for their clients in order to empower them so when clients are aware of what the lawyer is trying to achieve, they can bring more information to them, which, in turn, may be of help to the lawyer. It envisions the lawyer as someone who brings their expertise to work in collaboration with, rather than on behalf of, a number of different groups such as community leaders, community groups, agencies and allies with an openness to alternative methods of

$10 \quad$ Gary Bellow, 'Steady Work: A Practitioner's Reflections on Political Lawyering' (1996) 31 (2) Harvard Civil Rights - Civil Liberties law Review 297, 300

$11 \quad$ Parkdale Community Legal Services, 'Our Vision' < https://www.parkdalelegal.org/about/vision/> accessed 26 June 2020

12 David Nicolson, "'Our Roots Began in South Africa": Modelling Law Clinics to Maximise Social Justice Ends' (2016) 23(3) International Journal of Clinical Legal Education, 119 
resolving disputes other than the use of litigation although litigation is seen as a component of the lawyer's toolkit.

Communitarian social activists operating in different contexts have used approaches that have affinities with rebellious lawyering, as well as similar ways of working. What they have in common is they stress the importance of being embedded in community, working in non-hierarchical ways, and engaging in self-examination in order to be effective in bringing about social transformation.

For example, before rebellious lawyering theory had been developed, Mahatma Gandhi's theory of social change was born out of a struggle with colonialism. Although there are few explicit acknowledgements of Gandhi's theories in the literature on rebellious lawyering there are parallels and similarities between them. Like rebellious lawyers, Gandhi was sceptical about litigation, but not opposed to it, as a means of advancing the cause of marginalised communities; however, he was wary of its delays and cost. ${ }^{13}$ He saw arbitration and mediation as more effective methods of resolving disputes for the marginalised. ${ }^{14}$ Gandhi's concept of swadeshi which prescribed the path of commitment and service to "our immediate surroundings" resonates with the idea of the lawyer becoming embedded in the

13 Mahatma Gandhi Views on the Basic Issues of Social Change $<$ https://www.yourarticlelibrary.com/sociology/mahatma-gandhi-views-on-the-basic-issuesof-social-change/38489 > accessed 27 June 2020 ibid 
community, as well as ideas of localism and self-sufficiency within the environmental movement. ${ }^{15}$ His commitment to equality, including between intellectual and manual labour, anticipates the rejection of regnant lawyering in rebellious lawyering theory. He felt that there had to be a social purpose to education, so his ideas can take root in a clinical legal education setting. Above all, Gandhi was a transformational leader as he brought about a change in values and beliefs amongst his followers as to the best way to achieve change from initially wanting armed conflict with their colonial oppressors to the successful adoption of nonviolent resistance known as satyagraha.

Paolo Freire was one of the founders of critical pedagogy and felt that education could be the basis of social transformation for communities marginalised by capitalism. In Freiran theory teacher and leaner must enter into a dialogue and therefore must be in an equal relationship in order to learn from each other. This reflects in an educational setting the equality of relationship between lawyer and clients in rebellious lawyering. Teacher and learner must act together upon their environment in order to reflect critically upon their reality. However, not only must they reflect, they must also take action to change this reality, which is a concept called conscientization. A commitment to this approach requires constant selfexamination on the part of the teacher who must be prepared to be personally 
transformed by the experience. ${ }^{16}$ Freire's theories can act as a guide for applying rebellious lawyering theory in an educational setting as the objectives and ways of working are so similar. As in Frieran theory, in rebellious lawyering theory the lawyer and the community are in a reciprocal educative relationship: the lawyer must be open to learn from the communities they serve, and the community must be open to learning about legal process from the lawyer. As a concomitant to the lawyer's openness to learn from the community, they must also be open to selfrefection and adapt their lawyering model as their understanding of the communities they serve deepens. ${ }^{17}$

Naomi Klein's theories of social change have been developed in response to the climate crisis. She aims to organise a non-violent mass movement for climate action as she believes individual action by itself, whilst useful, is not sufficient to avert climate catastrophe. There has to be an organised fight for a major restructuring of our economic system, which usurps the reigning neoliberal ideology. She defines this as market fundamentalism involving deregulated capitalism, which needs to be replaced with an alternative worldview. The alternative will be "embedded in interdependence rather than hyper-individualism, reciprocity rather than dominance, and cooperation rather than hierarchy." 18 She recommends a strategic alliance between climate activists and activists in the various movements for social

\footnotetext{
16 Peter Mayo, Echoes from Freire for a Critically Engaged Pedagogy, (2013) Bloomsbury López (n 2) 355

Naomi Klein, This Changes Everything: Capitalism vs. the Climate (2015) Penguin, 462
} 
justice, based on their common interests and the galvanising effect of climate emergencies. This coalition building is necessary to defeat the forces of populism and is comparable to the need for coalition building that rebellious lawyers recognise they must do in order to be effective. As the present economic model based on endless growth is unsustainable, we have to examine ourselves and our consumerist values in order to reduce our over-consumption to sustainable levels. ${ }^{19}$ Economies need to be localised and we need to be more deeply connected with and knowledgeable about our communities, as the effects of climate change has subtly different impacts in different places. ${ }^{20}$

This thread of needing to constantly re-examine yourself in different theories of social change also finds expression amongst rebellious lawyers. They experiment with their collaborative work, "constantly re-evaluating their own institutional and personal efforts." 21 They have to be self-critical in reflecting on their own performance so they do not get hemmed in by their own "tiny habits". ${ }^{22}$ As rebellious lawyering requires continuous experimentation it has been said that it is not a methodology but "prescriptively normative" with principles guiding them as they evolve their legal pedagogy and practice. ${ }^{23}$ Rebellious lawyers regard themselves as only possessed of a partial truth. Whilst they hope their ideas will last

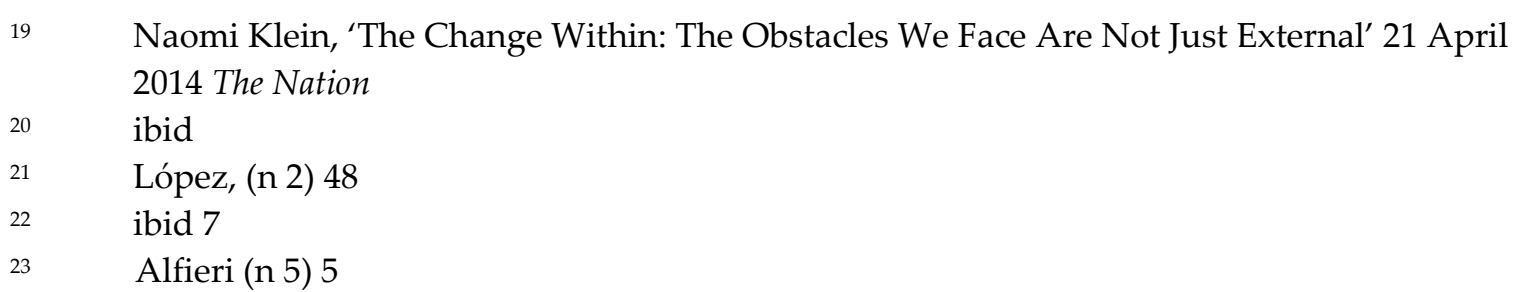


for a reasonable time, they are primarily striving to develop ideas about ways of seeing and talking about specific situations. They have to respond to the increase in knowledge they acquire about their communities over time and the changes in the institutions with which they have to deal. ${ }^{24}$

Rebellious lawyers must continuously reflect on their ability to work with, as opposed to on behalf of, certain groups. Do they have sufficient cultural knowledge and awareness to communicate effectively with that group? Are they sufficiently aware of how the law and changes to it permeate the lives of the groups they work with? Are they sufficiently aware of how local, regional, national, political, economic and cultural forces impact on their communities? They will be interdisciplinary in their methods drawing on ethnography, anthropology and sociology, in addition to law in order to understand their communities better. So, a rebellious lawyer is engaged in a constant process of self-examination. ${ }^{25}$ They need to reflect on their values, developmental needs, and reaction to situations before they can be agents of social change in similar ways to those advocated by Gandhi, Freire and Klein.

$24 \quad$ López (n 2) 65 - 66

$25 \quad$ López (n 2) 168 


\section{Sustainability and Sustainability Education}

It is submitted that the rebellious lawyering model is suited to inform the work of a university law clinic engaging in sustainability issues and provides useful guidance. Although rebellious lawyering theorists do not make much mention of sustainability it is inherent in their activities, as, indeed, it is already inherent in many university law clinic activities. It is striking that traditions of lawyering that are specifically rooted in sustainability come to similar conclusions as to the lawyer's role as facilitator and collaborator. ${ }^{26}$ Through its desire to link the local to the regional to the national to the global rebellious lawyering has a similar approach to those involved explicitly in sustainability, who also live by the motto, "act local, think global".

Educators have difficulty with sustainability due to the uncertainty of the concept, as there is no universally agreed definition. For the purposes of a university law clinic, the following definition of sustainability is useful:

26 Janelle Orsi, 'Birth of Sharing Law' (Shareable, 29 March 2010) <https://www.shareable.net/birth-of-sharing-law/> accessed on 13 September 2019. 'Community transactional law' or 'sharing law' has implications for the content and approach to legal practice. It sees collaboration between lawyer, client, and community as key. A more sustainable economic model will see a shift to more innovative sharing transactions such as bartering, cooperatives, community currencies, time banks. community supported agriculture, cohousing, and community gardens. This will mean that lawyers will more frequently represent groups of people, as opposed to individuals or businesses. This creates new challenges for the lawyer. For example, if a group of unrelated people wish to purchase a house together traditional legal ethics require that they each have their own lawyer to advance their interests "with zeal". However, zealous advocacy of a single party's interests may not be the best approach to achieve the shared objective. It may be more easily realised by facilitating an open and trusting relationship between the parties and mediate between them when disputes arise. 
"A sustainable future is one in which a healthy environment, economic prosperity and social justice are pursued simultaneously to ensure the wellbeing and quality of life of present and future generations. Education is crucial to attaining that future." 27

Sustainability education needs to be "approached through a 'whole systems thinking model'", which offers us a profound way to re-orientate our worldview, and also our educational thinking and practice." ${ }^{28}$ Whole systems thinking has three interrelated dimensions - perceptual, conceptual and practical - which describe human experience and knowledge at any level whether it be at the level of the individual, the community or whole societies. ${ }^{29}$

The perceptual way of thinking is intuitive ways of knowing. When a culture is individualistic there is little encouragement to think of "the other" whether that be communities, distant communities or future generations. Developing perceptual thinking requires an inner "deepening" process, which values all aspects of personhood, particularly intuition, and becomes aware of our individual and shared

27 Sustainable Ideas, 'sustainable Ideas!' < $<$ https://www.sustainable.id/> accessed on 29 June 2020. Other possible definitions are: "A process of change in which the exploitation of resources, the direction of investments, the orientation of technological development and institutional change are all in harmony and enhance both current and future potential to meet human needs and aspirations." Another possible definition is: "In essence sustainable development is about five key principles: quality of life; fairness and equity; participation and partnership; care for our environment and respect for ecological constraints - recognising there are 'environmental limits'; and thought for the future and the precautionary principle."

28 Stephen Sterling, Sustainable Education: Re-visioning Learning and Change (Green Books for the Schumacher Society) Kindle Edition, 874 ibid 890 
needs and worldviews. It requires the development of soft skills such as empathy. ${ }^{30}$ The conceptual way of knowing is the dominant way of knowing in the Western intellectual tradition. It seeks to develop critical and systemic understanding and pattern recognition. ${ }^{31}$ The practical way of knowing or praxis is often given a lesser status in the same tradition. ${ }^{32}$ This is the process of using knowledge in a practical way. Privileging the conceptual over the perceptual and practical ways of thinking, as happens in the Western educational tradition, breaks the connection between them. For example, in order to engage in legal practice striving to achieve sustainability goals for marginalised communities, clinical law students will need sound conceptual thinking. They will need to understand the scientific method behind issues such as air pollution. However, that by itself will not be enough to bring about transformational change. They will need to work effectively with people within that community and be able to empathise with them, that is, through the perceptual way of thinking, and work with them on the problems they are facing in order to bring about more sustainable solutions, that is, through the practical way of thinking.

There are clear synergies between whole systems thinking and rebellious lawyering theory. The latter stands in opposition to regnant lawyering with the lawyer who exists exclusively in the conceptual dimension cast in the pre-eminent role whereas 
the rebellious lawyer will draw on the practical and perceptual ways of knowing which exist in the communities they serve. This leads to a deeper and more integrated understanding of what is happening in these communities and therefore put them onto a more sustainable footing.

Considering how the past affects the present and the future offers possibilities both for rebellious lawyering and sustainability practice. The sociologist, Avery Gordon, seeks a new way of knowing called "social haunting" or a knowledge of "the things behind the things." 33 She says that "ghostly matters" - "echoes and murmurs of that which has been lost" - haunt us at every turn. ${ }^{34}$ Like rebellious lawyers, Gordon says we need new ways of knowing and radical political change cannot come without it. However, to Gordon the new way of knowing is achieved by recognising how the past affects the present.

"Social haunting", which can be defined as "a sense, a feeling, a way of thinking, an atmosphere that pervades within a community, influencing its future in myriad, perhaps unnoticed, ways," can enrich and inform rebellious lawyering practice. ${ }^{35}$ It enables new ways of seeing and listening to the communities rebellious lawyers serve; and it also offers the potential to enrich and inform the sustainability agenda.

33 Avery Gordon and Janice Radway, Ghostly Matters: Hauntings and the Sociological Imagination (University of Minnesota Press, 2018) vii ibid $x$ UK Research and Innovation, "Working with social haunting: past- and present-making in two "communities of value'" $\leq$ https://gtr.ukri.org/project/0B37892C-E08C-4AD8-BF1E9BA30FCDF8EB $\geq$ accessed 29 June 2019 
Klein used a similar idea specifically in the context of sustainability when she said we need to overcome the "culture of the perpetual present, one that deliberately severs itself from the past that created us as well as the future we are shaping with our actions." ${ }^{36}$ If we deepen our understanding of what shapes group behaviour, we increase the chance of bringing about behavioural change.

There have been studies in different branches of science which support Gordon's idea that a community's present and future is determined by the past. There is a relatively new area of study in psychology called intergenerational or transgenerational trauma, which posits that trauma can be transmitted through generations, so can affect later generations who did not live through the historical traumatic event via complex post-traumatic stress disorder mechanisms. This area of study commenced with research into the behaviour patterns of children of Holocaust survivors. Studies have also found that there has also been an impact on the behaviour of subsequent generations of indigenous Canadian and Native American populations caused by past oppression, as well as African-Americans caused by a history of slavery and racial discrimination. ${ }^{37}$ Intergenerational trauma has also been found to have been caused by sexual abuse and extreme poverty. It 
can affect communities, as well as families, by creating distrust of those outside the group, particularly those from historically oppressive groups. ${ }^{38}$

In addition to these behavioural studies, there has been neurological research which posits that the link between memory, imagination and simulating the future is physical. There is a common neural system, which supports our recollection of times past, imagination, and our attempts to predict the future. ${ }^{39}$ In other words, there is a physical link between our memory and our ability to imagine the future, as both use the same part of the brain: the hippocampus.

Gordon's identification of the limits of current disciplines and fields can be applied to other areas as well, and those areas are potential partners in the coalition building and network development that rebellious lawyers wish to see. Social work is seen as too often having an individual focus in a way which depoliticises "its response to problems exacerbated by poverty, social exclusion and limited life chance."40 Similarly, nursing is often seen as focussed on "an individualistic biomedical model that sees the biological individual as a system in itself disconnected from the

$38 \quad$ ibid

39 Sinéad Mullally and Eleanor Maguire, 'Memory, Imagination and Predicting the Future: A Common Brain Mechanism?' (2013) 20(3) The Neuroscientist 220

40 Andrew Whiteford, Viv Horton, Diane Garrad, Deidre Ford, and Avril Butler, 'Sustaining Communities: Sustainability in the Social Work Curriculum' in Paula Jones, David Selby and Stephen Sterling (eds) Sustainability Education (Earthscan 2010) 241 
environment." 41 Rebellious lawyers therefore when engaging in their selfexamination need to be aware not only that they have been educated in a discipline whose traditions and processes are highly individualistic but also, in many cases, their coalition and network partners have also been educated and practised in processes which are also highly individualistic and not accustomed to linking the specific to any wider structures.

\section{Putting 'social haunting' in context}

In an area like south Wales, where Swansea Law Clinic (the subject of the case study discussed below) is located, effects of de-industrialisation are still being felt. Many will have regarded their communities as having fought and lost an existential battle during the Miners' Strike of 1984 . There is an ongoing collective trauma caused by the conflict, so behavioural change will not come about unless there is a good understanding of how the past haunts the present and affects the future. For example, there are continuing feelings of demoralisation and loss of confidence created as a result of losing such a high stakes collective battle.

Many also remember when the economy transitioned away from heavy industry to service industries in the 1980s bringing with it high unemployment. ${ }^{42}$ This could

41 Benny Goodman and Janet Richardson, 'Climate Change, Sustainability and health in UK Higher Education: the Challenges for Nursing' in Paula Jones, David Selby and Stephen Sterling (n 35) 118

42 When there were large scale steel redundancies in South Wales in 1980 the unemployment rate rose from $7.7 \%$ to $15.7 \%$. S. Young, 'The implementation of Britain's national steel 
affect attitudes to change as the economy undergoes its next transition, which is away from a more carbon intensive economy to a low carbon or zero carbon economy.

Rebellious lawyers who are embedded in communities and knowledgeable about their clients lived experience will have greater appreciation of how the past affects the present and future, which will help them identify obstacles to change. However, being aware of the past, and how it affects the present, must not create a sense of inevitability about the future. Although currently economically challenged that does not mean the South Wales region is inevitably going to be so in the future. The way we envision the future draws on our pasts, but there are any number of combinations that can be used which draw on the present and the past when constructing a future. There can be different outcomes if there is a conscious decision to take decisions in different ways from in the past.

\section{Sustainable development legislation and the Well-being of Future Generations} (Wales) Act 2015 (the Act)

This section will assess the content of the Act and its implications for lawyering, as well as evaluating how rebellious lawyering methods might respond to it. In addition, it will further assess how it might influence a university law clinic's 
practice, which is using rebellious lawyering methods, when seeking to achieve sustainability goals.

The Act is the only legislation in the world, to date, to impose duties to protect the needs of future generations and to embed the United Nations Sustainable Development Goals into law. ${ }^{43}$ The legislation had first been suggested in 2002 by Victoria Jenkins, then a lecturer in law at Swansea University. ${ }^{44}$ There were later widespread calls for such an Act from civil society. For example, WWF had convened and supported thirty civil society organisations into the Sustainable Development Alliance, which called for such legislation. ${ }^{45}$

For the purposes of the Act, "sustainable development" means the process of improving the economic, social, environmental and cultural well-being of Wales. ${ }^{46}$ It requires the public bodies named in the Act to carry out sustainable development by acting in accordance with "the sustainable development principle". The definition of sustainable development used in the Well-being of Future Generations (Wales) Act 2015 is:

43 The Future Generations Report 2020 (Future Generations Commissioner for Wales, 2020) 14

$44 \quad$ Davidson (n 6) 1360

$45 \quad$ Davidson (n 6) 1461; Sustainable Development Alliance, 'Shaping Our Future' < http://www.shapingfuturewales.org/en/> accessed 7 September 2020

46 Well-being of Future Generations (Wales) Act 2015 s 2 
“...[acting] act in a manner which seeks to ensure that the needs of the present are met without compromising the ability of future generations to meet their own needs." 47

This is a definition of sustainable development, as opposed to sustainability. The difference between the two is often seen as sustainability being a long-term goal (that is, a more sustainable world) and sustainable development as the pathways and processes to achieve it, for example, sustainable production. ${ }^{48}$ The definition used in the Act follows the Brundtland definition. ${ }^{49}$ The definition in the Act is attempting to combine environmental protection with human, social and economic development concerns. The advantage of this is that it is easy to get broad acceptance of the principle of sustainable development, which will assist those practising rebellious lawyering to achieve the broad consensus, which will be helpful to their work.

The disadvantage of such a broad-ranging definition of sustainable development is that tensions can arise particularly between environmental concerns, on the one hand, and human, social and economic developments concerns, on the other. There is no inherent mechanism for resolving trade-offs between competing concerns

\footnotetext{
$47 \quad$ ibid s $5(1)$

48 'Sustainable Development' (UNESCO undated) < https://en.unesco.org/themes/educationsustainable-development/what-is-esd/sd> accessed 8 August 2019

49 World Commission on Environment and Development, Our Common Future "the Brundtland Report" (1987) Chapter 1, para. 49
} 
within the Act. This reality, combined with a lack of a common understanding as to what sustainable development means in practice, impedes its effectiveness. For example, the definition could justify a fiscally conservative approach as the burden of debt will be carried by generations as yet unborn, as well as justifying a deep ecological approach, which would be totally different.

The Act requires forty-four public bodies in Wales to work towards seven well-being goals $^{50}$ : 


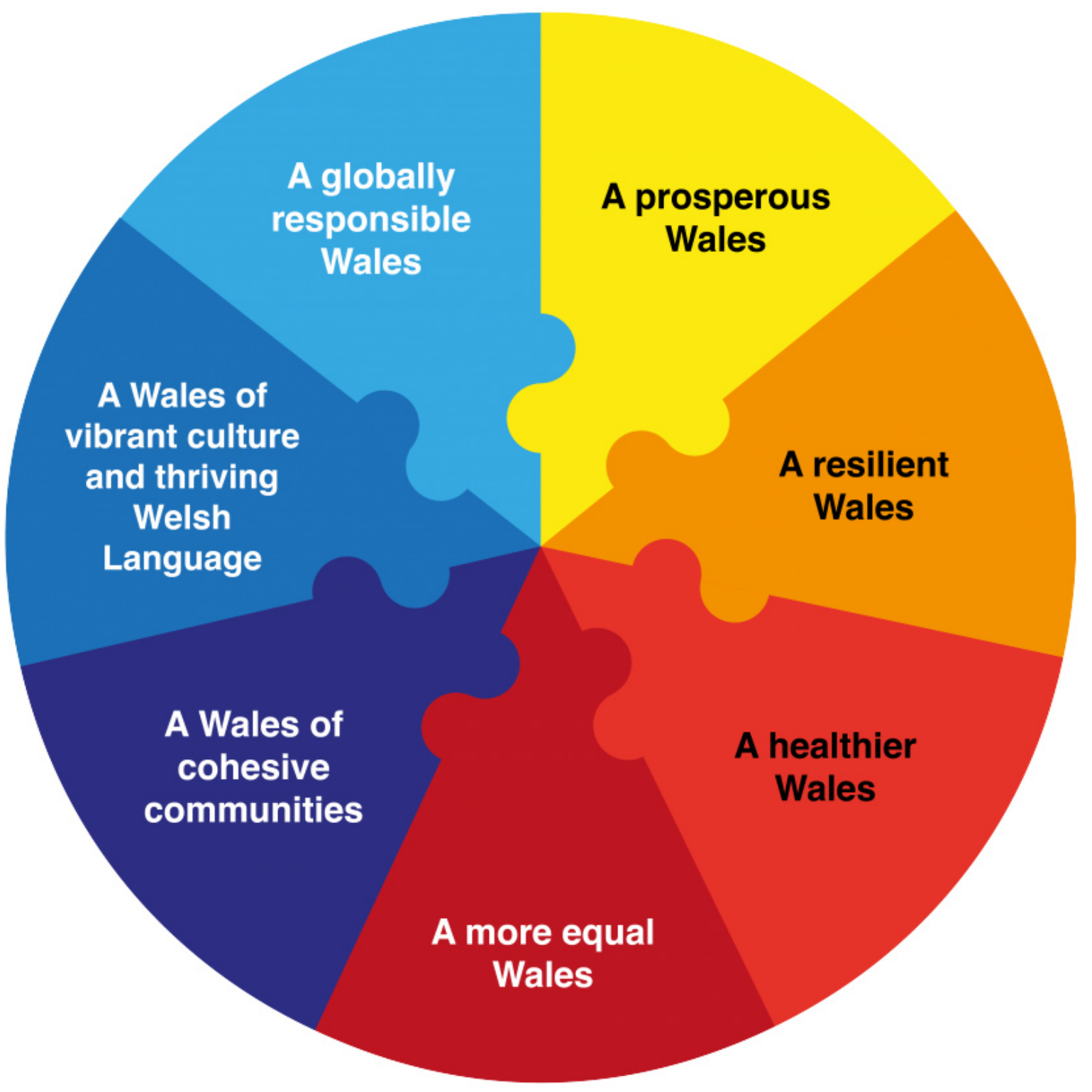

These goals have been described as "substantive commitment devices", which are mechanisms that commit policy makers to do certain sorts of things to protect longterm interests and enables the executive to be scrutinised for the effect its decision making is having on long-term interests. ${ }^{51}$ 
The Act also requires the Welsh government to publish "national indicators" that are to be applied to measure progress towards well-being goals; ${ }^{52}$ they must produce an annual well-being report "on the progress made towards the achievement of the well-being goals by reference to the national indicators and milestones"; 53 and within twelve months of a general election to the Welsh Parliament they must produce a Future Trends report. ${ }^{54}$ These have been called "procedural commitment devices", which do not require the government to do the right thing but publicly declare beforehand what they will do so they can be scrutinised and held to account. $^{55}$

There is no prioritisation of the goals, which are intended to be interlocking. However, if ecological sustainability were to have primacy within the principle then this priority would create an effective framework for decision-making and governance, as that would make clear that human, social and economic development must occur in an ecologically sustainable manner. ${ }^{56}$

Although a globally responsible Wales is one of the well-being goals, this goal is seen as a dilution of the Welsh Government's previous sustainable development

\footnotetext{
$52 \quad \mathrm{n} 46 \mathrm{~s} 10(1)$

$53 \quad \mathrm{n} 46 \mathrm{~s} 10(10)$

$54 \mathrm{n} 46 \mathrm{~s} 11$

$55 \mathrm{n} 51$

56 Andrea Ross, Sustainable Development Law in the UK From Rhetoric to Reality (Earthscan for Routledge, 2012) 4
} 
scheme which had the vision for Wales living within its environmental limits. ${ }^{57}$ At present, Wales consumes at a rate that would require 2.5 planets. ${ }^{58}$ Also, there is nothing in the Act which prevents Wales from exporting a lack of sustainability whilst remaining sustainable within its own borders by, for example, exporting plastic refuse to another State. There are those who would analyse the Act from a deep ecological perspective and would argue that sustainable development is a contradiction in terms. Their assertion is that as the Earth only has finite resources, there are limits to economic growth; so unlimited economic growth stands in opposition to environmental protection. ${ }^{59}$ From this perspective, "a prosperous Wales" which "recognises the limits of the global environment,"60 but is not absolutely required to live within them, would not go far enough.

The interlocking of goals and their lack of prioritisation will, however, be able to promote complexity thinking, which has been defined as follows:

"Systems are defined as complex because they are diverse and composed of multiple, interconnected, interdependent elements interacting in non-linear

\footnotetext{
$57 \quad$ Welsh Assembly Government (WAG), One Wales: One Planet The Sustainable Development Scheme of the Welsh Assembly Government (WAG 2009) 17

58 Stockholm Environment Institute and GHD, Ecological and Carbon Footprints of Wales Update to 2011 (Stockholm Environment Institute and GHD, 2015) John Alder and David Wilkinson, Environmental Law and Ethics (Palgrave, 1999) 141 as cited in Ross (n 56) 3

60 n 46 s 4
} 
ways. They are adaptive because they have the capacity to change and learn from experience, which gives rise to self-organisation or self-regulation." 61

Complexity thinking differs from linear thinking which can be defined as:

“...a process of thought following known cycles or step-by-step progression where a response to a step must be elicited before another step is taken." 62

Rebellious lawyers, by their nature, will engage in complexity thinking as they will wish to place their clients' experience within a wider context and examine how the interdependence of relationships will affect them, so the interlocking of the seven well-being goals will assist them in their practice, as well as being a template for the good life rebellious lawyers are envisioning.

When applying the sustainable development principle there are "five ways of working" which public bodies must follow. ${ }^{63}$ They are as follows:

i. $\quad$ Long-term ${ }^{64}$

Short-term needs must be balanced by the need to meet long-term needs.

\footnotetext{
61 Christine Gilligan Kubo, 'Understanding sustainable development in the voluntary sector: a complex problem' (Doctoral thesis) (2013) $61<$ http://shura.shu.ac.uk/9712/> accessed 15 August 2019

62 Frank van Empel, ‘Why Economists Are Always Wrong' (Ecolutie, undated) <https://www.ecolutie.nl/why-economists-are-always-wrong/ > accessed 15 August 2019

63 n 46 s 5(2)

$64 \quad$ n 46 s 5 (2) (a)
} 


\section{ii. $\quad$ Integration 65}

Public bodies must consider how their well-being objectives may impact upon each of the well-being goals, on their other objectives, or on the objectives of other public bodies.

\section{iii. $\quad$ Collaboration 66}

Public bodies must act in collaboration with any other person (or different parts of the body itself) that could help the body to meet its well-being objectives.

iv. Involvement ${ }^{67}$

Public bodies must involve people with an interest in achieving the well-being goals and ensure that those people reflect the diversity of the area which the body serves.

\section{v. Prevention ${ }^{68}$}

Public bodies must take account of preventing problems occurring or getting worse in order to achieve their well-being objectives.

It is submitted that rebellious lawyering theory is well suited to "the five ways of working." The requirement for public bodies to provide an integrative service means that they must relate differently not only to other public bodies but also to individuals, community groups, the third sector and businesses. This creates the

$\begin{array}{ll}65 & \text { n } 46 \text { s } 5(2)(\mathrm{b}) \\ 66 & \mathrm{n} 46 \text { s } 5(2)(\mathrm{c}) \\ 67 & \mathrm{n} 46 \text { s } 5(2)(\mathrm{d}) \\ 68 & \mathrm{n} 46 \mathrm{~s} 5(2)(\mathrm{e})\end{array}$


opportunity for university law clinics to work with public bodies in innovative ways and provide more innovative service to the economically challenged communities they often serve.

\section{Future Generations Commissioner}

The Act has also set up the post of a Future Generations Commissioner for Wales who is effectively the representative of future generations in policy making in Wales. ${ }^{69}$ She has the following statutory powers:

- Advise, encourage and promote ${ }^{70}$

- Research $^{71}$

- Carry out reviews ${ }^{72}$

- Make recommendations ${ }^{73}$

- $\quad$ Produce a Future Generations report ${ }^{74}$

- Receive advice from an Advisory Panel ${ }^{75}$

The Future Generations Commissioner is a potential ally to a rebellious lawyer. Her "name and shame" powers have the potential to further a rebellious lawyering agenda and she is in a position to promote socially transformative resolutions to

$\begin{array}{ll}69 & \text { n } 46 \text { s } 17 \\ 70 & \text { n } 46 \text { s } 19(1) \\ 71 & \text { n } 46 \text { s1 } 9(2) \\ 72 & \text { n } 46 \text { s } 20 \\ 73 & \text { n } 46 \text { s } 21 \\ 74 & \text { n } 46 \text { s } 23 \\ 75 & \text { n } 46 \text { s } 26\end{array}$


disputes other than through the use of litigation. University law clinics can inform her work not only through their data but also by highlighting the Academy's work in creating new solutions to sustainability issues.

Although in certain respects, the Future Generations Commissioner for Wales is a unique role, there have been several attempts at enhancing foresight and the scrutiny of long-term governance in policy making around the globe. The attempts that have been made have been diverse and include specialist legislative committees, future-focused forums, parliamentary commissions and independent commissioners with mandates to address long-term issues, government ministries and various advisory arrangements. ${ }^{76}$

One of the most established initiatives is Finland's Committee for the Future, which is a parliamentary committee established in the 1990s. One of its main functions is to prepare a parliamentary response to the Finnish government's Reports on the Future and to date has responded to seven such reports. ${ }^{77}$

Although Scotland's Futures Forum was established over thirteen years ago under the auspices of the Scottish Parliament, it is not a parliamentary committee or any

76 Jonathan Boston, David Bagnall and Anna Barry, Foresight, insight and oversight: Enhancing long-term governance through better parliamentary scrutiny (Institute of Governance and Policy Studies, Victoria University of Wellington, 2019) 114

$77 \quad$ ibid 119


formal part of the parliamentary structure. It is not intended as a scrutiny mechanism but is a channel for public engagement with the Scottish Parliament by encouraging dialogue with long-term issues, as well as promoting research on such issues.

Singapore's approach has been to develop a think tank, the Centre for Strategic Issues, which is part of the executive and since 2015 has been part of the Strategy Group in the Prime Minister's Office.

A number of countries have devised new institutions to address long-term issues. These countries include Hungary, which has a Commissioner for Future Generations; Tunisia, which has a Sustainable Development and the Rights of Future Generations Commission; Gibraltar, which has a Commissioner for Sustainable Development; New Zealand which has a Parliamentary Commissioner for the Environment (whose remit is focussed on the environment, but not wider sustainability issues) and Israel, which had a Commission for Future Generations, now abolished. ${ }^{78}$

78 House of Lords, 'Protecting and Representing Future Generations in Policymaking Debate on 20 June 2019 Library Briefing' 7 - 10

$<$ https://researchbriefings.parliament.uk/ResearchBriefing/Summary/LLN-2019-

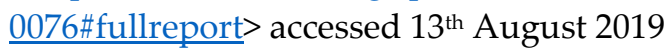


The United Arab Emirates have tried a different type of institutional innovation through the establishment of a "Ministry of Possibilities", the world's first virtual ministry to apply design-thinking and experimentation to develop proactive and disruptive solutions to tackle critical issues. The Ministry brings together national and local government, the private and voluntary sectors in order to consider radical changes in government systems, to adopt new innovative models and to work in ways that take calculated risks. ${ }^{79}$

At the time of writing, there are also legislation and policy changes in train in Portugal and Canada, as well as a Future Generations Bill before the UK parliament, which have looked to the Welsh model for inspiration. ${ }^{80}$ If Canada and the UK were to provide some kind of sustainability lead - whether through institutional change or scrutiny devices of the type mentioned above - they would be countries with significantly larger populations than any of Wales, Finland, Scotland, Singapore, Hungary, Tunisia, Gibraltar, New Zealand or the United Arab Emirates; all of these have populations of fewer than twelve million people. ${ }^{81}$ Canada's population is thirty-two million and the United Kingdom's is sixty-seven million. ${ }^{82}$

\section{$79 \quad \mathrm{n} 4312$}

80 Wellbeing of Future Generations Bill [HL] 2019-21. The UK Bill has a similar structure to the Welsh Act including creating a Future Generations Commissioner for the UK. However, in certain important respects it goes further. If public bodies do not follow the proposed UK Commissioner's recommendations the Commissioner, following an investigation, may apply to court for an order that the public body comply with the recommendations or take such action as the court specifies.

81 The population of Finland is 5.5 million; Scotland 5.4 million; Singapore 5.6 million; Hungary 9.6 million; Tunisia 11.8 million; Gibraltar 33,700; New Zealand 5 million; Israel 8.6 million; 
The Welsh Government Minister who sponsored the Act, Jane Davidson, has said:

"I am strongly of the belief that there are particular opportunities for a small country to be a test bed; to be smarter and more flexible than its larger neighbours. Here cultural behaviour-change experiments can be piloted and new approaches forged." 83

It can indeed be easier for a small country to bring relevant stakeholders together and to make the links between production, consumption and well-being. Leadership on sustainability issues enables a small country to extend its soft power. They can be influential through leading on sustainability ideas, which can then be rolled out to larger countries who can benefit from the prior experience of small countries.

Institutional change and scrutiny devices are one approach. By contrast, another approach to sustainability has seen attempts to pivot the management of the economy away from a focus on Gross Domestic Product to instead consider a wider range of well-being objectives. New Zealand has adopted a Well-being Budget with five priority areas to focus on areas where there are the greatest opportunities to

Wales 3.1 million and United Arab Emirates 9.8 million. $\leq$ worldmeters.info $\geq$ accessed 3 July 2020

82 Source: $<$ worldmeters.info $>$ accessed 3 July 2020

83 Davidson (n 6) 159. Jane Davidson was Minister for Environment and Sustainability in Wales from 2007 to 2011 where she was responsible for the Welsh Government agreeing to make sustainable development its central organising principle. 
make an impact. ${ }^{84}$ It also plans a work programme across government to embed well-being. ${ }^{85}$

There is evidence that having these institutional structures to promote sustainability in place seems to stimulate international cooperation on sustainability issues. The UN Sustainable Development Goal 17 provides:

A successful development agenda requires inclusive partnerships - at the global, regional, national and local levels - built upon principles and values, and upon a shared vision and shared goals placing people and the planet at the centre. ${ }^{86}$

As a result, some of the governments with a progressive sustainability agenda Scotland, New Zealand, Iceland, and Wales - have started collaborating in the Wellbeing Economy Governments Partnership. ${ }^{87}$ The main objective of the partnership is to promote collaboration and learning on sustainability issues and share experiences. Since 2017, the Future Generations Commissioner for Wales has Chaired the Network of Institutions for Future Generations of similar commissioners

$84 \quad$ New Zealand Government, 'How does Budget 2019 deliver a wellbeing approach?' < https://www.budget.govt.nz/budget/2019/wellbeing/approach/how-does-b19-deliver.htm> accessed 7 May 2020

85 ibid

$86 \quad$ United Nations, 'Goal 17: Revitalize the global partnership for sustainable development' < https://www.un.org/sustainabledevelopment/globalpartnerships> accessed 30 June 2020

87 Wellbeing Economy Alliance, 'Wellbeing Economy Governments' < https://wellbeingeconomy.org/wego> accessed 30 June 2020 
or bodies with responsibilities for representing the needs of future generations across the globe. Its general goals include collaborating and sharing best practice; encouraging the establishment of similar institutions worldwide; raising awareness of the need for well-being of future generations; and working with international organisations, such as the United Nations, to protect "the interests, rights and wellbeing of future generations" ${ }^{88}$ It would seem, therefore, that if a university law clinic is located in a nation which has some sort of institutional structure to safeguard the interests of future generations then there will also be international networks that will collaborate on learning about sustainability issues, which the clinics may benefit from indirectly.

The experience of countries that have taken a lead on sustainability issues shows that this leadership can create an impetus to deepen their engagement; however, continued progress is by no means assured. The experiences of Hungary and Israel, in particular, show the need to develop a broad consensus that supports long-term preventative planning. In Hungary, the Commissioner for Future Generations operated from 2008 but the Commissioner's powers "were significantly reduced" in 2012 under a new constitution. It has been suggested that the reduction of the Commissioner's powers may have been due to a "deficit of political understanding of, or sympathy for, its goals and methods", and may have resulted from its "notable

88 Network of Institutions for Future Generations, '2018 Mission Statement' $\leq$ https://www.ajbh.hu/documents/2238847/2939231/Mission+Statment final/1f2ba67d-5498c24e-9f4c-1bbec523e203 $\geq$ accessed 30 June 2020 
interventions in private and governmental interests". ${ }^{89}$ Viktor Orbán's assumption of the premiership of the Hungarian government in 2010 with his use of nationalist populism has resulted in a reduction on the checks and balances on the executive, including those designed to protect the interests of future generations. ${ }^{90}$

In Israel the Commission for Future Generation's role was to give opinions on any legislation which affected future generations. This included holding an "effective veto" on legislation which did not comply with the interests of future generations. The Commissioner could also initiate bills and "play a general advocacy role to parliament". ${ }^{91}$ The Commission was disestablished in 2016 apparently "for budgetary reasons". However, it is thought that its wide-ranging powers may have been a factor in its demise. ${ }^{92}$

Research into sustainable development agrees that there should be a broad cultural acceptance and understanding across national communities that prioritises operating and thinking about the long-term effects of policies and decisions. ${ }^{93}$ The experience of Hungary and Israel show that without a strong base of support for sustainability initiatives amongst communities and civil society then even if they

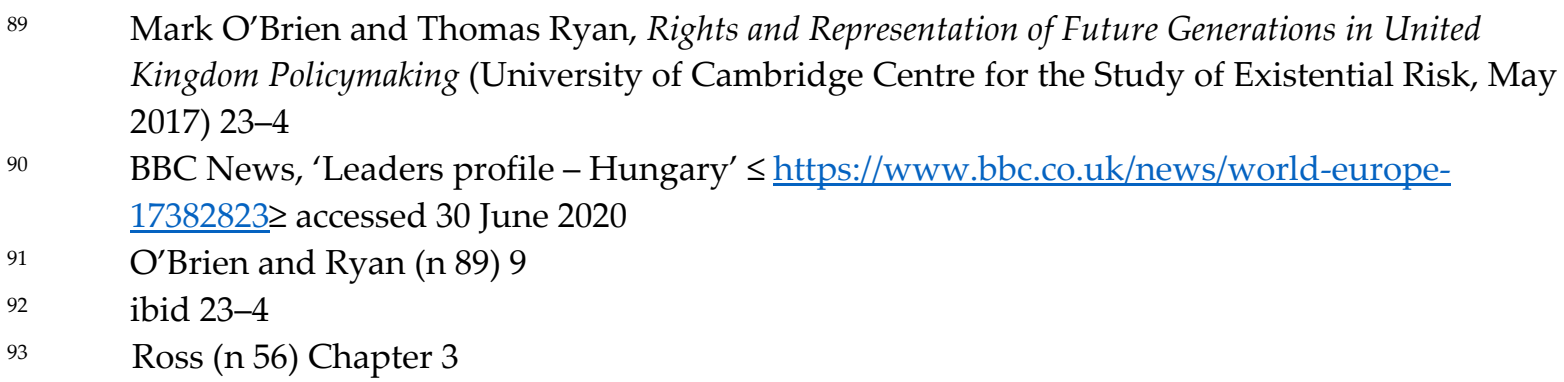


have impact there will be a reversion back to governmental short-termism later. For example, the Israeli Commission was not the product of calls from civil society or popular demand. It was largely the idea of one politician, Joseph (Tommy) Lapid, who served as the Deputy Prime Minister and Minister of Justice. When he retired from politics, the Commission lost its champion and ceased to exist shortly after his retirement. ${ }^{94}$ Whilst in Hungary, the President was anxious that the post of Commissioner for Future Generations be as independent as possible, so he dispensed with the usual informal process of discussing with political parties as to who was the most suitable candidate. Consequently, there was a lack of cross-party support for the eventual appointee. ${ }^{95}$

The more successful and long-lasting attempts at future generational representation, such as in Finland and Wales, have been established against a backdrop of significant support from civil society. ${ }^{96}$ This support is a further challenge to, or opportunity, for rebellious lawyering practice to build a consensus for a sustainability agenda amongst coalitions and networks.

94 Jonathan Boston, David Bagnall and Anna Barry, Foresight, insight and oversight: Enhancing long-term governance through better parliamentary scrutiny (Institute of Governance and Policy Studies, Victoria University of Wellington, 2019) 127

95 Sándor Fülöp, 'The Hungarian Experience' in Anna Nicholl and John Osmond (eds) Wales' Central Organising Principle: Legislating for Sustainable Development (IWA in association with WWF Cymru and Cynnal Cymru/Sustain Wales, 2012) 74

96 Natalie Jones, Mark O'Brien and Thomas Ryan, 'Representation of future generations in United Kingdom policy making' Futures, 102 (2018) 153, 161 
Although the Future Generations Commissioner for Wales has relatively weak powers and does not have a power to initiate or veto legislation in the same way as the Israeli Commissioner had, this might make the office itself more sustainable. The Future Generations Commissioner for Wales could be in a transitional position with greater powers accruing over time as the benefits of a more preventative, long-term approach become apparent, and support for increased powers builds across the political spectrum, as well as amongst communities and civil society. The chances of success will also be enhanced where civil society creates greater public awareness of sustainability issues. ${ }^{97}$

\section{Litigation involving the Act}

The Act through its use of "substantive and procedural commitment devices" has provided new tools for the legislature to engage in "forward-looking scrutiny" of the executive, as opposed to the more traditional approach of scrutinising something the executive has already done. ${ }^{98}$ These attempts to get public bodies to think about the long-term enhance good governance. Although there are a number of international examples of advisory bodies, scrutiny devices and institutional arrangements to get the public sphere to think long-term, there is "nothing as yet internationally, which is identical and as comprehensive and integrated as the Welsh model." 99 However,

\footnotetext{
$97 \quad$ ibid 153,161

$98 \quad$ Boston, Bagnall and Barry (n 94) 11

99 n 51
} 
the Act has been less successful as a way of providing individuals with legally enforceable rights.

This seems to be demonstrated by one of the first challenges which used the Act as a ground for judicial review. ${ }^{100}$ A local authority wanted to close a school. The school had falling numbers and the local authority wished to move pupils to another school, which would involve some students in up to a sixty-minute drive from home. Opponents of the closure argued that closing the school would "rip the heart out of the community" so the attractiveness, viability, safety and connectedness of the community would be undermined contrary to the Act. ${ }^{101}$

Despite these arguments the application was denied. Mrs Justice Lambert said:

"I do not find it arguable that the 2015 Act does more than prescribe a highlevel target duty which is deliberately vague, general and aspirational and which applies to a class rather than individuals. As such, judicial review is not the appropriate means of enforcing such duties."102

\footnotetext{
$100 \quad R(B) v$ Neath Port Talbot County Borough Council CO/4740/2018

$101 \quad \mathrm{n} 46$ s 4 Table 1

102 Paul Martin, 'Law to protect future generations 'useless'” (BBC, 15 May 2019)

<https://www.bbc.co.uk/news/uk-wales-48272470 > accessed on 13 August 2019
} 
She went on to say that the closure of the school was "not inconsistent" with the local authority's published "well-being objectives", so was compliant with the Act anyway. ${ }^{103}$

Setting aside concerns about the strength of the campaigners' case, as there was specific legislation on school closures, some have argued that there was no need to have recourse to the Act which is a framework piece of legislation. Perhaps the case shows traditional lawyering was not the best approach and a rebellious lawyering approach with its scepticism of litigation and preference for coalition building may have been more effective. There is evidence that the public in Wales have difficulty accessing judicial review, in any event, as judicial review claims are comparatively low in Wales compared to most regions of England. ${ }^{104}$

Mrs Justice Lambert is doubtless right as far as the law is concerned: the Act can only be used to challenge decisions on procedural grounds, such as a clear conflict with a local well-being plan, but the behavioural change through complexity thinking, which the Act promotes, is difficult to challenge though legal process. The wellbeing duty placed on public bodies by the Act was also held to be too general and

\footnotetext{
$103 \mathrm{n} 100$

104 Sarah Nason, Understanding Administrative Justice in Wales: Full Report Including Executive Summary (University of Bangor, 2015) 19
} 
aspirational in nature to be directly enforceable through judicial review in a further case. ${ }^{105}$

The former Chief Justice of England and Wales, Lord Thomas of Cwmgiedd, writing extra-judicially, has also labelled the Act "aspirational legislation" and has said that the Act should not have been enacted, as the duties are not drafted in a form which is enforceable and there is no mechanism for enforcement. This lack of enforcement mechanism is "detrimental to the Rule of Law." 106

$105 \quad R$ (the British Association for Shooting and Conservation and Others) v Natural Resources Wales: $\mathrm{CO} / 4881 / 2018$ legislation' (The Lord Renton Lecture Institute of Advanced Legal Studies) 21 November 2019 $<$ http://www.statutelawsociety.co.uk/home/lord-thomas-text-aspirational-legislation-21-11$\underline{19 /}$ > accessed 30 June 2020. In his lecture Lord Thomas sets out five possible enforcement mechanisms: i. A Court/tribunal where the Commissioner (or an individual) can challenge a decision of a public body and the court/ tribunal adjudicates on the merits of whether the decision complies with the duty; ii. The court/ tribunal instead of deciding on the merits of compliance applies a judicial review test to the decision of the public body; iii. An ombudsman or similar person with an adjudicative role who decides the same questions; iv. A Commissioner/auditor who considers whether the decision complies with the duty and is given the power to go to court to enforce compliance or has the power to enforce itself; v. A Commissioner/auditor who simply reports on non-compliance or reports to an ombudsman. The UK Future Generations Bill is similar to the Welsh Act in many ways. However, it proposes stronger enforcement measures. If a public body does not follow the proposed UK Future Generations Commissioner's recommendations, then following an investigation, the Commissioner can apply for a court order to require the public body to comply with the recommendation or make such other order as the court specifies (s 26). An individual can apply to court when a public body breaches its obligations or refer the matter to the Commissioner for an investigation (s 27). The court is also able to impose a fine on the public body (s 28). 
Although there will be few cases where the Act, as currently drafted, will be the basis of a successful challenge using an application for judicial review, it has been successfully used by individuals to challenge planning decisions. ${ }^{107}$

Lawyers using a rebellious lawyering approach want duties that are capable of individual enforcement and are consistent with the Rule of Law. They want detail provided to accompany high level aspirational well-being duties, which, for example, fully spell out what is meant by a right to adequate housing. However, the impact on them of a lack of an enforcement mechanism through judicial review is small. They have a scepticism about the ability of legal process to positively affect their clients' lives, as, amongst other things, this assumes their clients can access the legal process in the first place. The Act is meant to promote a dialogic approach using integrated, participative and collaborative methods where interdependence of human and non-human stakeholders is recognised. A hierarchical approach such as judicial review where decisions are imposed through an adjudicative process will inevitably be rarely used by them.

107 This refers to a planning decision relating to Cae Calon, Martletwy, nr Narberth, Pembrokeshire Planning Application Ref:16/0549/PA. There was a prospective One Planet Development Policy planning application, which was initially refused by the local planning authority. However, it was subsequently approved on appeal by the Planning Inspectorate in December 2017. Of particular note is planning inspector Nicola Gulley's comment: "In reaching this decision, I have taken into account the ways of working set out at section 5 of the Well-Being of Future Generations (Wales) Act 2015 and I consider that this decision is in accordance with the sustainable development principle through its contribution towards one or more of the Welsh Ministers well-being objectives set out as required by Section 8 of the Well-Being of Future Generations Act." One Planet Council, 'Approved Applications" < http://www.oneplanetcouncil.org.uk/approved-applications/> accessed 6 September 2020 


\section{A success for rebellious lawyering methods? The M4 relief road}

Where the Act clearly has had impact is in relation to the Welsh government's decision over the M4 relief road. This was a proposed motorway, south of the city of Newport in South Wales and was intended to tackle congestion around the city on the existing motorway. The proposed alternative route would have passed through an environmentally sensitive area known as the Gwent Levels. Eventually, the First Minister of the Welsh Government decided to reject the planned road on grounds of both cost and the environment. ${ }^{108}$

The decision could be seen as a vindication of a rebellious lawyering approach. A coalition had been built between a number of environmental groups and local residents who were also able to enlist the support of the Future Generations Commissioner for Wales.

The decision gives some guidance as to how the Welsh Government will handle the trade-offs which are an inherent part of sustainable development. One of the Act's well-being goals is a "resilient Wales" which is defined as:

108 Decision letter of First Minister of Welsh Government re: various schemes and orders in relation to the M4 corridor around Newport 04/06/2019

<https:/gov.wales/sites/default/files/publications/2019-06/m4-corridor-around-newportdecision-letter.pdf $>$ accessed 13 August 2019 
"A nation which maintains and enhances a biodiverse natural environment with healthy functioning ecosystems that support social, economic and ecological resilience and the capacity to adapt to change (for example climate change)." 109

However, another goal is to create 'A prosperous Wales', which is defined as:

"An innovative, productive and low carbon society which recognises the limits of the global environment and therefore uses resources efficiently and proportionately (including acting on climate change); and which develops a skilled and well-educated population in an economy which generates wealth and provides employment opportunities, allowing people to take advantage of the wealth generated through securing decent work." 110

A coalition of NGO environmental groups, local campaigners and the Commissioner for Future Generations was opposed to the relief road mainly for environmental reasons. All of this is consistent with a rebellious lawyering approach. However, there were other coalitions in favour of the relief road which argued that there were environmental arguments in favour of the new road. These included increasing congestion on the existing road leading to increased $\mathrm{CO}_{2}$ emissions, as well as the

109 n 46 s 4 Table 1

$110 \quad$ n 46 s 4 Table 1 
need for the new road for the economic development of the area. Although there were local residents in favour of the relief road, the most high profile campaigners were business groups led by the Confederation of British Industry (CBI) Wales who felt that it was needed in order to increase the prosperity of South Wales as well as to improve the public transport infrastructure and that steps could be taken to significantly mitigate the environmental damage so that only $2 \%$ of the Gwent Levels would be affected.111 They also felt that increasing active travel would not be enough to solve the problem.

It is submitted that the "prescriptively normative" principles which guide rebellious lawyering would mean that rebellious lawyers would presumptively side with those opposing the relief road. In 2016 Newport had 7.08 tons of $\mathrm{CO}_{2}$ emissions, which was in the third highest category of emissions in the UK. ${ }^{112} 28 \%$ of households in Newport are without a car or a van, which made the whole debate of limited relevance to them. ${ }^{113}$ It would also mean that expenditure on a major road project would not be addressing their transport needs, further exacerbating inequalities. Rebellious lawyering is primarily a form of lawyering which seeks to address

111 Leighton Jenkins, 'Discover more about the M4 relief road and the benefits it presents to the Welsh economy' (CBI 23 April 2019) <https://www.cbi.org.uk/policy-focus/infrastructureand-energy/articles/cbi-calls-on-welsh-government-to-build-m4-relief-road/> accessed 14 August 2019

112 Centre for Cities, Cities Data Tool <https://www.centreforcities.org/datatool/\#graph=map\&city=show-all\&sortOrder=high\&indicator=co2-emissions-per-

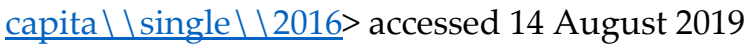

113 Hugh Mackay, Campaign Against the Levels Motorway 'The M4 Relief Road: a failed idea out of step with 21 ${ }^{\text {st }}$ Century Wales' (Nation Cymru, $3^{\text {rd }}$ December 2018) $<$ https://nation.cymru/opinion/the-m4-relief-road-a-failed-idea-out-of-step-with-21st-centurywales/ > accessed 14 August 2019 
inequalities caused by the subordinated not being able to access legal proceedings, and not faring well when they do.

In making these trade-offs between resilience and prosperity decision makers are also hampered by the fact that the future is, of course, uncertain. It is possible for example that at some future date electric cars will be so common that they will have lower carbon emissions than public transport alternatives such as trains. But it is only possible to rely on current data to decide where trends such as these are leading. If the decision had been taken to build the relief road campaigners said they would have brought an application for judicial review. ${ }^{114}$ However, as can be seen from $R(B) v$ Neath Port Talbot County Borough Council ${ }^{115}$ judicial review applications are determined on procedural grounds, and campaigners would have found that very difficult. In this context, there was an argument for saying that the relief road met the prosperity goal, and was in keeping with well-being plans, and the science over $\mathrm{CO}_{2}$ emissions was contested between the campaign groups.

A rebellious lawyering approach, particularly one adopted by a university law clinic, seems to have a lot to offer in this type of situation. As rebellious lawyers, clinic practitioners will be cautious about the use of litigation and will begin with the approach that other methods will be preferable. A university law clinic has the

$\begin{array}{ll}114 & \text { ibid } \\ 115 & \text { n } 100\end{array}$


opportunity to build an interdisciplinary coalition within the university, particularly in the scientific community, to input further evidence into what is often already a high-profile debate.

\section{Developments in policy}

If the Act as presently drafted is not capable of individual enforcement, it nevertheless has had significant impact in changing behaviour in some areas of policy.

Planning law has been re-designed to align with the sustainable development principle. ${ }^{116}$ As a result, "the planning system is to adopt a placemaking approach to plan making, planning policy and decision making." 117 This is a clear sign of commitment from the Welsh government; however, aligning the planning rules to

116 Planning Policy Wales Edition 10, (Welsh Government, 2018)

117 ibid para. 2.9. "Placemaking" is a holistic approach to the planning and design of development and spaces, focused on positive outcomes. It draws upon an area's potential to create high quality development and public spaces that promote people's prosperity, health, happiness, and well-being in the widest sense. Placemaking considers the context, function and relationships between a development site and its wider surroundings. This will be true for major developments creating new places as well as small developments created within a wider place. Placemaking should not add additional cost to a development, but will require smart, multi-dimensional and innovative thinking to implement and should be considered at the earliest possible stage. Placemaking adds social, economic, environmental and cultural value to development proposals resulting in benefits which go beyond a physical development boundary and embed wider resilience into planning decisions. 
the policy will take time. ${ }^{118}$ This has the potential to create more cohesive communities which can be supported by the work of rebellious lawyers in clinics. ${ }^{119}$

Education policy has also responded to the Act. The education curriculum for 3 16-year olds will be significantly overhauled starting from 2022, which is designed to help practitioners to develop a more integrated approach to learning and which aligns to the sustainable development principle by promoting systemic thinking. ${ }^{120}$ Analysis of the change from a sustainability perspective has called for: n 43 Chapter 5

119 Since 2011 the Welsh Government has also adopted the One Planet Development Policy. In order to meet the criteria of one Planet Development Policy "...residents of One Planet Developments have to live quite differently (much more sustainably) than is the norm in the 21st century" Welsh Government, Practice Note One Planet Development Technical Advice Note 6 (Welsh Government, October 2012) 2. The essential characteristics of One Planet developments in the open countryside are that "they must have a light touch on the environment; be land based - the development must provide for the minimum needs of residents in terms of food, income, energy and waste assimilation in no more than five years; have a low ecological footprint - the development must have an initial ecological footprint of 2.4 global hectares per person or less with a clear potential to move to 1.88 global hectares per person over time...; have very low carbon buildings - these are stringent requirements, requiring that buildings are low in carbon in both construction and use; be defined and controlled by a binding management plan which is reviewed and updated every five years; and be bound by a clear statement that the development will be the sole residence for the proposed occupants" ibid. This is seen by the Welsh Government as a niche initiative and not something to scale up, Max Baring, 'Want to save the planet? Move to Wales' (Thompson Reuters Foundation, 2 August 2018) < https://news.trust.org/item/201808021000032bwnt\#: : :text=The\%20'One\%20Planet\%20Development $\% 20$ Policy, the $\% 20$ resources $\% 20$ they $\%$ 20are\%20due.> accessed 6 September 2020. In 2018, 32 households had applied for planning permission under the One Planet Development Policy. Hwb, 'Developing a vision for curriculum design' $\leq \underline{\text { https:/hwb.gov.wales/curriculum-for- }}$ wales/designing-your-curriculum/developing-a-vision-for-curriculum-design/\#curriculumdesign-and-the-four-purposes $\geq$ accessed 2 July 2020. It creates four purposes for learners to become: ambitious, capable learners, ready to learn throughout their lives; enterprising, creative contributors, ready to play a full part in life and work; ethical, informed citizens of Wales and the world; and healthy, confident individuals, ready to lead fulfilling lives as valued members of society. It creates six areas of learning and experience: Languages, Literacy and Communication; Mathematics and Numeracy; Science and Technology; Humanities; Health and Well-being; and Expressive Arts. Individual disciplines still have an important role; however, the six Areas are seen as bringing them together to encourage strong 
“...more formal links between Welsh schools and the businesses, representative bodies, public sector employers, charities and others, links with whom would improve authentic learning for children..." 121

It is submitted that this connected approach to primary and secondary education will provide a better grounding for students before embarking on clinical legal education, as students will have had a greater amount of experiential learning before starting at university. ${ }^{122}$

\section{Communities of practice}

As the Act cannot be used as the basis for challenging decisions under judicial review efforts need to be directed towards coalition building. Gilligan Kubo argues for non-hierarchical Communities of Practice - groups of people who share a concern or a passion for something they do and learn how to do it better as they interact

and meaningful links between disciplines. There is a cross-cutting focus in literacy, numeracy and digital competence. School and the Future Generations Commissioner for Wales, 2019) 22 Although not arising directly as a result of Welsh Government policy, although drawing inspiration from it, there is an interesting higher education and sustainability initiative taking place in Wales. The Black Mountains College (BMC), which is based in the Brecon Beacons National Park, will launch the BMC degree - a Bachelor of Arts and Science degree - in September 2022, which will address the challenge of living sustainably. It will use short immersive teaching blocks with modules taught sequentially; spending time in nature; class sizes of twenty students; an interdisciplinary approach integrating information using all senses; a final year project working on a real-world problem; collaboration between students, tutors, industry partners and the local community Black Mountains College, 'The BMC Degree' < https://blackmountainscollege.uk/study/higher-education/> accessed 6 September 2020. 
regularly - as a way of encouraging civil society to promote sustainable development. ${ }^{123}$

Gilligan Kubo says that Communities of Practice using complexity thinking will support social learning - the theory that new behaviours can be acquired by observing and imitating others - "and encourage cognitive restructuring which can lead to behaviour change". ${ }^{124}$ Among the barriers to civil society promoting sustainable development are a lack of understanding of the need for behavioural change to support sustainable development, which is in turn linked to a lack of understanding of the systemic nature of such development, as well as the lack of staff capacity. ${ }^{125}$ This lack of staff capacity is an issue not just for civil society but for all sectors: how to create the headspace to understand sustainable development and develop behavioural change? Most services catering for the needs of the subordinated are very busy with their clients and struggle to find the time for this type of developmental work.

To work optimally, Gilligan Kubo sees Communities of Practice encouraging the engagement of diverse stakeholders, so that their different voices and perspectives are heard. For example, this would include voluntary sector staff, managers,

\footnotetext{
123 Gilligan Kubo (n 61) 200. An example of a Community of Practice, in the form of the Townhill Children's Zone, is discussed in the case study on the Swansea Law Clinic where a law clinic, schoolteachers, medics, youth workers and a community centre are working together to achieve sustainability objectives. ibid 207
} 
volunteers, service users, local government and local community representatives. ${ }^{126}$ However, given their lack of staff resource and how busy they are servicing the everyday needs of their clients, they will only want to engage in Communities of Practice when there is something of practical benefit to them. ${ }^{127}$

It is difficult to demonstrate quantifiable benefits to those in the voluntary sector interested in being involved in Communities of Practice using a complexity theory approach where outcomes cannot be closely predicted or guaranteed. ${ }^{128}$ This is where having legislation which seeks to protect the interests of future generations can be advantageous. The Well-being of Future Generations (Wales) Act 2015 binds forty-four public bodies in Wales, including the Welsh government and local authorities. These public bodies will only wish to fund and work with the voluntary sector if they are striving to achieve the seven well-being goals and using the "five ways of working" under the Act. The Welsh government has established and provides administrative support to Regional Advice Networks where advice agencies can discuss areas of mutual interest and set the agenda themselves. This provides a suitable forum for the advice sector to develop their Communities of Practice. It can provide support in creating the "headspace" for civil society to think about sustainability issues and promote the need for behavioural change. It could also be a way of engaging in coalition building which is not only central to rebellious

$\begin{array}{ll}126 & \text { ibid 211 } \\ 127 & \text { ibid 203 } \\ 128 & \text { ibid 19 }\end{array}$


lawyering practice, but also a way to build support for sustainability approaches amongst civil society. This creates demonstrable benefits for the voluntary sector when deciding whether to engage in Communities of Practice.

\section{Public Service Boards}

Another reason - and opportunity - for civil society to be well organised within the context of the Well-being of Future Generations (Wales) Act 2015 is the Act's provision for Public Service Boards. ${ }^{129}$ These boards consist of representatives of the local authority, health board, the local fire and rescue service and the Natural Resources Body for Wales. ${ }^{130}$ They must also invite, among others, at least one body representing relevant voluntary organisations. ${ }^{131}$ Public service boards are required to prepare and publish a local well-being plan setting out their local well-being objectives and the steps it proposes to take to meet them. ${ }^{132}$ This offers an opportunity for Communities of Practice to impact on local policy. If they can achieve consensus through their dialogue the Community of Practice can speak with one voice through its representative on public service boards.

$\begin{array}{ll}129 & \text { n 46 s } 29 \\ 130 & \text { ibid s } 29 \\ 131 & \text { ibid s } 30(1)(\mathrm{e}) \\ 132 & \text { ibid s 39 }\end{array}$




\section{Sustainability and clinical legal education}

This section will look at how university law clinics can apply rebellious lawyering principles to achieve sustainability objectives. It will consider some of the urgent issues around developing attributes amongst students in order to make them effective sustainability practitioners.

According to UN Educational Scientific and Cultural Organisation (UNESCO), higher education is seen as having a particular role to play in promoting sustainability:

“Higher education should emphasise experiential, inquiry-based problemsolving learning, interdisciplinary systems approaches and critical thinking." 133

There is a clear synergy here between clinical legal education, which is a form of experiential, inquiry-based, problem-solving approach using critical thinking, and interdisciplinary learning. This is so despite the fact that many law schools find the interdisciplinary approach challenging. The way many universities are governed with different subjects managed in different faculties and different cost centres often

133 UNESCO, 'UNESCO Decade of Education for Sustainable Development (2005 - 2014) Draft International Implementation Scheme (UNESCO 2004)' cited in Paula Jones, David Selby and Stephen Sterling 'Introduction' in Paula Jones, David Selby and Stephen Sterling (n 35) 2. UNESCO have also produced learning objectives for the sustainable goals $\leq$ https://unesdoc.unesco.org/ark:/48223/pf0000247444 $\geq$ accessed 2 July 2020 
acts as one of the main inhibitors to interdisciplinary learning. These challenges can be overcome, amongst other things, by an institution-wide sustainability strategy and external stimuli such as external grants. ${ }^{134}$

Sustainability can be a value-laden ontology and there have been fears within the Academy that an uncritical embrace of the sustainability agenda is a threat to academic freedom. When the Higher Education Funding Council for England (HEFCE) circulated their consultation document Sustainable Development in Higher Education they received the following response from Dr Peter Knight, Vice Chancellor of the University of Central England:

“It is one of the most pernicious and dangerous circulars ever to be issued. It represents the final assault on the last remaining freedom of universities...It is not the job of universities to promote a particular orthodoxy; it is their role to educate students to examine critically policies, ideas, concepts and systems, then make up their own minds." 135

There are a number of responses which could be made to this. First, sustainability itself does not promote any orthodoxy among economic models. For example, there are those who think that neo-liberal marketisation is unsustainable and that there

\footnotetext{
134 Paula Jones, David Selby and Stephen Sterling 'Introduction' in Paula Jones, David Selby and Stephen Sterling (n 35) 10 - 11

135 Peter Knight, 'Unsustainable Developments' (The Guardian, 8 February 2005)
} 
has to be a fundamentally new approach taken to the economy. However, there are those who think that if capitalism is restructured and appropriately regulated it can operate on a sustainable basis. If neo-liberal marketisation is not examined and critiqued, then there is a risk of inadvertently promoting it as the orthodoxy, i.e. the only way to organise an economy, so it is necessary to look at alternative economic models.

Secondly, tutors should demonstrate "epistemic humility": being humble with their assumptions about understanding. If a student does not think climate change is anthropogenic in nature then tutors need to engage with this challenge meaningfully, and not be dismissive. It should be viewed as an opportunity for critical discussion, which is beneficial for everyone. It will also mean that counterarguments can be foregrounded and discussed.

Even issues such as climate change, whose existence cannot be seriously contested as $97 \%$ of climate scientists believe that there is global warming, can still be discussed with students because responses to it can vary from a fundamental reorganisation of the economy to less challenging adaptations or improvements in technology. ${ }^{136}$ 
There are a number of general principles frequently used in sustainability pedagogies including participatory and inclusive education processes, transdisciplinary cooperation, experiential learning and the use of environment and community as learning resources; all of which involve an interactive enquiry-based approach to teaching and learning. ${ }^{137}$ All these requirements have a natural affinity not only with clinical legal education but also with rebellious lawyering practice.

Whatever students' stance on sustainability, and climate change in particular, they should be encouraged to develop a "personal environmental ethic". ${ }^{138}$ In developing this "personal environmental ethic" legal clinicians should see this as integral to developing students' well-being. Consider that there has been an "extinction of experience" in childhood. ${ }^{139}$ In the 1950s 40 per cent of British children regularly played in natural areas. This has dropped to 10 per cent today, with 40 per cent of children never playing outdoors at all. ${ }^{140}$ On the basis of this observation, it is reasonable to assume that many, if not the majority, of legal clinical students have had little experience of the outdoors. This is significant for two reasons.

\footnotetext{
137 Debby Cotton and Jennie Winter, 'It's Not Just Bits of Paper and Light Bulbs': A Review of Sustainability Pedagogies and the Potential for Use in Higher Education in Paula Jones, David Selby and Stephen Sterling (n 35) 41 - 42

$138 \quad$ Joy Palmer and Philip Neal, The Handbook of Environmental Education (Routledge 1994) 19

139 Masashi Soga and Kevin Galston, 'Extinction of experience: the loss of human-nature interactions' (2016) 14(2) Frontiers in Ecology and the Environment 94 - 101 
First, one in six of the UK population suffers from depression, anxiety, stress, phobias, suicidal impulses, obsessive compulsive disorder or panic attacks sometimes in combination. Anxiety with depression is the most common disorder. ${ }^{141}$ E.O. Wilson called the human connection with nature "biophilia", which he defined as the "rich, natural pleasure that comes from being surrounded by living organisms". ${ }^{142}$ Studies have shown that symptoms of common mental disorders are alleviated with time spent in nature, as well as an increase in positive mood. ${ }^{143}$

Secondly, studies show that children who spent time in green spaces between the ages of seven and twelve tend to think of nature as magical. ${ }^{144}$ As adults they are more concerned about lack of nature protection, while those who have no such experience tend to be more indifferent to its loss. ${ }^{145}$ They will therefore have a less developed "personal environmental ethic". ${ }^{146}$

\section{Case study: Sustainability and the Swansea Law Clinic}

In order to participate in a clinic of this transformative nature, students need to be supported to put the issues in context whether through pre-reading and/or a suitable

\footnotetext{
$141 \quad$ William Bird, Natural Thinking (Natural England and RSPB 2007) 7

142 Edward Osborne Wilson, Biophilia: The Human Bond with other Species' (Harvard University

Press, 1984) 157:

$143 \quad$ Tree (n 140) 295

$144 \quad$ ibid 294

145 ibid 294

146 John Baines, 'Learning to Live on Planet Earth. The Environmental Approach to Education' (1986) 5(1) Environmental Education and Information
} 
induction programme, in order to develop their capacity to reflect on such issues. ${ }^{147}$ They need to be aware of major challenges such as the climate crisis, loss of biodiversity, use of plastics, inequalities, pandemics and the effect of automation, and how political, economic, social and cultural forces contribute to these issues. They also need to be encouraged to think about their own personal vision as to what a sustainable world would be like, which puts into a profound sustainability context the rebellious lawyer's idea of a good life.

As sustainability clinics are aiming to promote systemic change, it is necessary to examine with students how all these issues intertwine. The Clinic's induction training has to begin by making the links. For example, examining the relationship between environmental degradation, inequality and gender. Thus, student advisers may not necessarily realise that research studies have shown the single most important thing can be done is to increase communities' resilience to natural disaster is reducing educational inequality between the sexes. ${ }^{148}$

The ideal induction programme, as at Swansea, seeks to develop students' perceptual way of thinking through thinking about client care. It explores various emotional states, how they may be identified and how a distressed client may affect

\footnotetext{
147 Adrian Evans, 'Greenprint for a Climate Justice Clinic: Law Schools' Most Significant Access to Justice Challenge' (2018) 25(3) International Journal of Clinical Legal Education 7, 13 
the students' own well-being, and what they should do to promote their well-being. The conceptual way of thinking is developed through building on the students' existing knowledge of legal doctrine. The practical way of knowing is developed through the acquisition of professional skills.

As Swansea Law Clinic has small businesses as well as individuals as clients, students' commercial awareness around sustainability issues can be developed. The United Kingdom has passed legislation setting a goal of net zero carbon emissions target by $2050 .{ }^{149}$ In order to meet this target companies will need to develop plans, so students need to be aware that climate change is, in certain circumstances, a material financial risk. For example, it is estimated that net zero emissions will lead to $80 \%$ of coal assets and half of developed oil reserves being stranded. ${ }^{150}$ If they are to have the commercial acumen to meet the needs of clients in the future they need to know the risks and opportunities inherent in transitioning.

They also need to be aware of how central a lawyer's role can be in formulating business practice and company policy. When surveyed, 93\% of in-house lawyers globally said when their company had a sustainability plan, they led, contributed or influenced the company's efforts. ${ }^{151}$ Therefore, there is a need for university law

\footnotetext{
149 Climate Change Act 2008, s 1, as amended by The Climate Change Act 2008 (2050 Target Amendment) Order 2019, SI 1056, s 2

$150 \quad$ Mark Carney, 'Today' (BBC Radio Four, 30 December 2019)

151 Association of Corporate Counsel, '2019 ACC Chief Legal Officers Survey Corporate Social Responsibility' (30 January 2019) < https://www2.acc.com/governance/upload/New-ACC-
} 
clinics to promote the development of lawyers who have a good grasp of sustainability principles and some experience of applying them.

Given the scale and complexity of issues such as climate change and growing inequalities, students' creativity needs to be nurtured and developed in order to develop the innovative solutions required. Some of Swansea Law Clinic's students are working towards module credits as part of their undergraduate law degree. They can opt out of the normal assessment, and, with agreement, work on a project of their own choosing on some aspect of how the Clinic can contribute to well-being goals as set out in the Well-being of Future Generations (Wales) Act 2015 and/or local well-being plans.

Creativity is something very difficult to teach, but innovative approaches to litigation are increasingly a form of sustainability activism, particularly when it comes to climate change. Raising awareness of these developments could spark students' creativity. Innovative litigation strategies, such as ClientEarth's challenge to the UK government to bring forward new clean air quality plans, are considered. ${ }^{152}$

ESGinfosheet.pdf? ga=2.233523102.1403026587.1588687862-40775737.15886687862> accessed 5 May 2020 
The growing body of future generations' strategic litigation around the world is often youth-led so it is not only a subject worthy of study in its own right but also can be an effective way of engaging students. The issues facing future generations such as climate change, rising inequalities, increasing automation, etc. are so complex and, in many cases, novel that the fresh perspectives that students can provide are valuable. Models of youth-led leadership are empowering and can help students develop their confidence in putting their ideas forward.

Climate action lawsuits have spread to twenty-eight countries around the world with more than 1,300 actions brought since 1990. ${ }^{153}$ These lawsuits have been placed into two categories: strategic and routine cases. ${ }^{154}$ Strategic cases often see the "parties seek to leverage the litigation to instigate broader policy debates and change". ${ }^{155}$ Routine cases are less visible cases, dealing with, for example, planning applications. They use original climate change arguments. These might influence governments and private bodies, but that is an incidental purpose. ${ }^{156}$ Such cases are creative in the way they use human rights arguments and draw on scientific

\footnotetext{
153 Joana Setzer and Rebecca Byrnes, Global trends in climate change litigation: 2019 snapshot (Centre for Climate Change Economics and Policy, Grantham Research Institute on Climate Change and the Environment and Sabin Center for Climate Change Law at Columbia Law School, July 2019)

ibid 2

Setzer and Byrnes (n 153) 2

ibid
} 
advancements to provide causal links between particular sources of emissions and climate-related harm. ${ }^{157}$

Although the youth-led action against the United States federal government for violation of constitutional rights to a safe climate was eventually thrown out on admissibility grounds in Juliana $v$. United States ${ }^{158}$ it could be seen to have value for its impact on policy debates. Although rebellious lawyering practice views litigation as just one tool in a toolkit to support oppressed communities, and is sceptical about its accessibility in many cases, this nuanced use of litigation as a way of advancing policy discussion or introducing new arguments into legal process can be seen as a part of rebellious lawyers' armament.

At Swansea Law Clinic, student advisers are required to safeguard their own mental and physical well-being, as well as develop their own well-being plans. During induction, they are advised as to stress reduction techniques which includes spending time in nature. This has the advantage of not only offering support if they are experiencing difficulties managing their stress levels but also, as research shows that time spent in nature positively affects attitudes towards it, they will have an enhanced awareness of the importance of biodiversity. ${ }^{159}$ However, it has to be recognised more needs to be done in this regard. In order to profoundly affect

\footnotetext{
$157 \quad$ ibid

158 Juliana $v$ United States US Court of Appeals Ninth Circuit, No. 18-36082 [2020]

$159 \quad$ Bird (n 141) 7
} 
attitudes towards nature, experiences of nature need to be integrated into education from childhood and at present, this is just one issue covered in the induction programme.

Involvement in environmental issues exacts a price in emotional labour. What is more, this collective emotional toll appears to be growing. ${ }^{160}$ Terms have been coined to describe the emotional experience of environmental collapse such as "solastalgia", which is when your "endemic sense of place is being violated"; 161 "eco anxiety" which has been defined by the American Psychological Association as chronic fear of environmental doom; ${ }^{162}$ and "ecological grief" which has been defined as "the grief reaction stemming from the environmental loss of ecosystems by natural and man-made events." 163

Students are required to reflect on how their experiences in the Clinic have affected their values in a personal reflection, which is part of the self-examination needed in rebellious lawyering practice. Here students have an opportunity to reflect on the development of their "personal environment ethic" as part of this assessment, so

160 Britt Wray, ‘Prequel: At The Beginning There Was Change’ (Climate of Emotions: Supporting Youth Wellbeing online conference $<$ https://www.youtube.com/watch?v=FpkEW1CE7nI> streamed live 21 April 2020, accessed on 29 April 2020)

161 Glenn Albrecht cited in Nicola Ross, from 'Language, Nature and the Great Remembering' The Journal of Wild Culture (16 September 2017)

162 Ashlee Cunsolo and others (eds) Mental Health and our Changing Climate: Impacts, Implications, and Guidance (American Psychological Association, Climate for Health and ecoAmerica 2017) 29

163 Kriss Kevorkian cited in Jordan Rosenfeld, 'Facing Down "Environmental Grief": Is a Traumatic Sense of Loss Freezing Action Against Climate Change?' Scientific American (Philadelphia, 21 July 2016) 
they also can self-scrutinise their behavioural change. In encouraging students to do this, law clinics must recognise that they will need to support them through their emotional reactions.

Whilst most within the sustainability community talk of the need for adaptation or mitigation when it comes to climate change there is a yet more radical strand that talks of the need for "deep adaptation". ${ }^{164}$ This approach does not seek to engage with methods of climate adaptation as it is premised on the view that social collapse, as a result of climate change, is now almost inevitable and human extinction possible. ${ }^{165}$ This approach requires moving on from the concept of sustainability, and instead examining what near-term societal collapse will look like. ${ }^{166}$

The risk is that the complex nature of global sustainability issues could lead students to develop feelings of fear, hopelessness and despair, which in turn causes paralysis. This state needs to be acknowledged and contained if it is to lead on to effective action. Many law clinics already practise containment methods such as mindfulness techniques. What is also needed is the space to process these feelings leading to action, which Swansea Law Clinic aims to do through personal reflection. Clinics in

\footnotetext{
$164 \quad$ Jem Bendall, ‘Deep Adaptation: A Map for Navigating a Climate Tragedy' (IFLAS Occasional Paper 2, 27 July 2018) < http://lifeworth.com/deepadaptation.pdf> accessed 1 May 2020 165 ibid 20

166 Melinda Harm Benson and Robin Kundis Craig. 'The End of Sustainability' 27 Society and Natural Resources (2014) 777
} 
their nature are action-led, and the feeling of taking action is one of the most effective ways of countering the various forms of eco-anxiety.

Swansea Law Clinic students are also given a grounding in the principles of the Act as part of their initial induction and training, which makes it clear that university law clinics have a role in developing the Act's principles. Public Service Boards have found the production of local well-being plans difficult to manage and as a result are playing it "safe" and using arguably weak forms of sustainable development using a narrow form of data. ${ }^{167}$ There has also been found to be a compliance culture around the production of local well-being plans. ${ }^{168}$

University law clinics have rich sources of data on the reality of living in their local communities, which can inform local well-being plans. They are also often in a position to use anonymised client stories or narratives. Use of stories is a technique often used in rebellious lawyering practice and can be used by law clinics as a technique to enable people to empathise with subordinated communities. ${ }^{169}$ Use of locally connected "icons" has also been shown to be the most effective way of

\footnotetext{
167 Alan Netherwood, Andrew Flynn and Mark Lang Well-being Assessments in Wales: An Overview Report (Netherwood Sustainable Futures, Cardiff University and Mark Lang Consulting 2017) 3

$168 \quad$ ibid 4

169 Richard Owen, 'Gathering the Excluded Voice: The TXT Inside/TXT Outside Project' (2014) 21 (1) International Journal of Clinical Legal Education 5 - 41
} 
engaging people in sustainability issues. ${ }^{170}$ Use of stories and "icons" is a product of the close relationship university law clinics have with their local communities, and their insights into how "social haunting" might act as a brake on behavioural change, also have the potential to enhance local well-being plans.

\section{Local Area Coordination}

The Clinic is located within the local authority area of Swansea Council. The Council is already innovating in the delivery of its service in a way which aligns with the Act. Local Area Coordination was a programme initially developed in Western Australia in 1988 in response to the urgent need to find new and innovative approaches for supporting people with learning disabilities and their families. ${ }^{171}$ It has been taken up in New Zealand, Ireland and other parts of the United Kingdom, and the idea has expanded to include supporting people facing all types of challenge.

Swansea Council has set up a network of Local Area Coordinators and the Clinic has been working with the Coordinator for the town of Gorseinon. The coordination approach is designed to take a preventative and collaborative approach in tackling some of the more deep-seated health and social care challenges the community faces,

\footnotetext{
170 Saffron J. O'Neill and Mike Hulme, 'An iconic approach to representing climate change' (2009) 19 Global Environmental Change 402-410

171 Ralph Broad, Local Area Coordination: From Service Users to Citizens (The Centre for Welfare Reform, 2012) 12
} 
such as an ageing population which is economically pressed during a time of austerity. Local Area Coordinators are embedded into the community, and work with all demographics to reduce dependence and build long-term resilience. An evaluation of the Local Area Coordination in Swansea and the neighbouring local authority area found:

\begin{abstract}
“There is an emphasis on nurturing trusting and supportive relationships with individuals and families which can take time to develop, building reliance and supportive connections to reduce the risk of future crisis and service dependency." 172
\end{abstract}

Service users are not viewed as passive recipients but as assets who have natural authority and are partners in the project of building community resilience. Swansea Law Clinic has been involved on a monthly basis in a Community Pop-up Café and One Stop Advice Shop which was initially established by the Local Area Coordinator. The café is run by local people and involves local elected officials, faith leaders, local based police officers, local authority officials and up to twenty different advice agencies. This enables the Clinic to give a more holistic service to clients and embodies principles of collaboration between and integration of services, all of which are part of sustainability agendas and rebellious lawyering. For example,

\footnotetext{
172 Caring Together and Swansea University, Local Community Initiatives in Western Bay: Formative Evaluation Summary Report (April 2016) 3
} 
when advising a client on a potential unfair dismissal claim the advice session with the Clinic will end by advising the client to mitigate their loss. Then the client will be referred on immediately to a back-to-work adviser who will assist the client on the spot to find work. The Clinic will further assist the client by showing them how they need to evidence their work searches for the Employment Tribunal.

The Local Area Coordination programme is not a requirement under the Act but is further evidence of how the Act has brought about behavioural change.

Finally, the Clinic is also part of the Townhill Children's Zone. This again is a multiagency initiative which serves an economically challenged part of the city. It consists of the head teachers of the local schools, medical practitioners who serve the locality, community youth workers, a local youth centre, as well as the Clinic. It draws inspiration from the Harlem Children's Zone and has as its aim to increase the number of children from the locality who attend university. Its focus is very much on long-term planning, which aligns with the Act's well-being goals, as well as collaboration and the integration of services. Again, the construction of local networks is also consistent with rebellious lawyering practice.

\section{Conclusion}

Rebellious lawyering deepens understanding of communities, builds broad-based coalitions, envisions a better life and strengthens awareness of how legal practice 
relates to big structures. As such, it is a form of sustainability legal practice, which can be practised in any jurisdiction. Its "normative principles" provide guidance to a university law clinic seeking to achieve sustainability objectives regardless of location, and in efforts to address the climate emergency at a local level. The Welsh experience also shows that where sustainability legislation does not exist academia and civil society - and university law clinics exist at the intersection of both - can have an important leadership role in bringing it about.

The value added to rebellious lawyering practice by sustainability legislation is that it creates a structure to improve long-term public decision making that extends beyond the electoral cycle. The Well-being of Future Generations (Wales) Act 2015 only seems to provide a mechanism for individual enforcement in exceptional cases, which deprives traditional public lawyers of a fundamental tool of their trade, judicial review. This is as much concern to rebellious lawyers, as it is to lawyers using a traditional approach. If challenges based on the Act face continuous defeat in the courts the public may become cynical about its effectiveness. The experience of Israel and Hungary shows that sustainability initiatives cannot be maintained if they lack broad public support. However, the impact of a lack of an individual enforcement mechanism on rebellious lawyering practice will be small, even if such lawyers and law clinics do need to work with others to get the Act amended so that an individual enforcement mechanism is inserted into it. The present situation can 
be viewed as a valuable transitional period, which can be used to build up support for the Act across civil society.

Whilst it is hard to quantify change, and the application of the Act by public bodies is at an early stage, there is much evidence it has already improved policies and behaviour, as shown by changes to planning and education policy in Wales. It has also brought about behavioural change in local authority operational practice as shown by the Local Area Coordination programme.

The lesson from Wales is that it takes time for sustainability legislation to be embedded across different policy areas, as a result of the complexity of systemic thinking. Time may not be on the side of any current species, as in 2018 the UN Intergovernmental Panel on Climate Change - which only deals with one aspect of sustainability - said urgent and unprecedented action would need to be taken in the twelve years if climate catastrophe is to be averted. ${ }^{173}$ So the challenge for the clinical legal education movement is to absorb and apply these lessons rapidly.

173 V. Masson-Delmotte and others (eds), Global Warming of $1.5^{\circ} \mathrm{C}$. An IPCC Special Report on the impacts of global warming of $1.5^{\circ} \mathrm{C}$ above pre-industrial levels and related global greenhouse gas emission pathways, in the context of strengthening the global response to the threat of climate change, sustainable development, and efforts to eradicate poverty (UN Intergovernmental Panel on Climate Change, 2019) 